\title{
PERBANDINGAN PERILAKU USAHATANI PADA DUA SENTRA PRODUKSI MANGGA DI PROVINSI JAWA BARAT (Kasus di Kabupaten Indramayu dan Kuningan)
}

\author{
COMPARISON OF FARMING BEHAVIOR \\ IN TWO MANGO PRODUCTION CENTERS IN WEST JAVA PROVINCE \\ (Cases in Indramayu and Kuningan Districts)
}

\author{
Rani Andriani Budi Kusumo*, Elly Rasmikayati, Tuti Karyani, Gema Wibawa Mukti \\ Program Studi Agribisnis Fakultas Pertanian Universitas Padjadjaran \\ J1. Raya Jatinangor Sumedang Km. 21 \\ *Email: raniandriani081@gmail.com \\ (Diterima 22-01-2019; Disetujui 15-07-2019)
}

\begin{abstract}
ABSTRAK
Beberapa daerah sentra penghasil mangga di Jawa Barat mengalami penurunan produksi yang cukup besar pada tahun 2016, hanya Kabupaten Indramayu yang mengalami peningkatan produksi manga; sebaliknya Kabupaten Kuningan mengalami penurunan produksi terbesar dibanding daerah lainnya. Kesenjangan hasil produksi di Kabupaten Indramayu dan Kuningan diduga terkait dengan perbedaan perilaku usahatani. Tujuan dari penelitian ini adalah untuk menganalisis perbedaan perilaku petani dalam usahatani mangga di Kabupaten Indramayu dan Kuningan. Penelitian ini merupakan penelitan kuantitatif dengan menggunakan metode survey-explanatory. Pengambilan sampel dilakukan dengan teknik multi-stage random sampling dengan total responden petani mangga sebanyak 130 orang. Analisis perbedaan perilaku petani dalam melaksanakan usahatani mangga di Kabupaten Indramayu dan Kuningan dilakukan dengan menggunakan uji mann Whitney dan chi square. Hasil penelitian menunjukkan tidak terdapat perbedaan perilaku petani dalam hal perawatan tanaman, penerapan pemupukan dan penggunaan zat pengatur tumbuh. Terdapat perbedaan perilaku petani di Kabupaten Indramayu dan Kuningan dalam pengendalian organisme pengganggu tanaman (OPT), dimana sebagian besar petani di Kabupaten Indramayu intensif dalam mencegah dan mengatasi serangan OPT, sedangkan sebagian petani di Kabupaten Kuningan belum intensif dalam mengendalikan serangan OPT. Sebagian besar petani di Kabupaten Indramayu telah menerapkan teknologi off season, dan sebaliknya sebagian besar petani di Kabupaten Kuningan belum menerapkan teknologi off season.
\end{abstract}

Kata kunci: perbedaan, perilaku, usahatani, produksi, mangga

\begin{abstract}
Several regions of mango producer centers in West Java experienced a significant decline in production in 2016, only Indramayu District experienced an increase in mango production; on the contrary, Kuningan Regency experienced the largest decline in production compared to other regions. The production gap in Indramayu and Kuningan districts is allegedly related to differences in farming behavior. The purpose of this study was to analyze differences in the behavior of farmers in mango farming in Indramayu and Kuningan districts. This research was quantitative research. This research method used survey-explanatory methods. Sampling had been taken by multi-stage random sampling technique. with a total of 130 mango farmers. To analyze differences in farmer's behavior in carrying out mango farming in Indramayu and Kuningan districts, a mann Whitney test and chi square test were used. The results of the study show that there were no differences in farmer behavior in terms of plant care, application of fertilization and use of growth regulators. In terms of controlling plant pest organisms (OPT) there were differences in the behavior of farmers in Indramayu and Kuningan Districts, where most farmers in Indramayu Regency were intensive in preventing and overcoming pest attacks, while some farmers in Kuningan Regency have not been intensive in controlling pest attacks. Most farmers in Indramayu Regency have implemented off-
\end{abstract}


season technology, and conversely most farmers in Kuningan Regency have not implemented offseason technology.

Keywords: differences, behavior, farming, production, mangoes

\section{PENDAHULUAN}

Provinsi Jawa Barat merupakan salah satu sentra produksi mangga di Indonesia. Varietas yang banyak diusahakan oleh petani antara lain gedong gincu, arumanis, dan cengkir. Daerah penghasil mangga di Provinsi Jawa Barat tersebar di Kabupaten Kuningan, Cirebon, Majelengka, Sumedang dan Indramayu.
Produksi mangga di beberapa daerah penghasil mangga dalam beberapa tahun terakhir mengalami fluktuasi yang beragam. Beberapa daerah sentra penghasil mangga di Jawa Barat mengalami penurunan produksi yang cukup besar pada tahun 2016, hanya Kabupaten Indramayu yang mengalami peningkatan produksi mangga (Tabel 1).

Tabel 1. Produksi Mangga di Daerah Sentra Mangga Jawa Barat

\begin{tabular}{|c|c|c|c|c|c|c|c|}
\hline \multirow{2}{*}{ Kabupaten } & \multicolumn{6}{|c|}{ Produksi Mangga (ton) } & \multirow{2}{*}{$\begin{array}{c}\text { Peningkatan Produksi } \\
\text { dalam Tahun Terakhir }(\%)\end{array}$} \\
\hline & 2011 & 2012 & 2013 & 2014 & 2015 & 2016 & \\
\hline Kuningan & 44.868 & 39.377 & 32.406 & 23.329 & 32.108 & 12.919 & $-59,74$ \\
\hline Cirebon & 55.981 & 62.053 & 30.945 & 51.661 & 37.443 & 31.086 & $-16,98$ \\
\hline Majalengka & 43.280 & 48.521 & 10.243 & 57.172 & 64.394 & 37.529 & $-41,72$ \\
\hline Sumedang & 21.169 & 29.008 & 23.607 & 20.633 & 23.491 & 23.403 & $-0,37$ \\
\hline Indramayu & 63.057 & 68.506 & 84.788 & 72.436 & 69.737 & 90.643 & 29,97 \\
\hline
\end{tabular}

Tabel 1 menunjukkan Kabupaten Kuningan merupakan daerah yang mengalami penurunan produksi cukup signifikan yaitu sebesar $-59,74 \%$. Kesenjangan hasil produksi di beberapa daerah pada tahun terakhir menimbulkan pertanyaan adakah perbedaan perilaku usahatani yang diterapkan di daerah yang mengalami penurunan produksi terbesar (Kabupaten Kuningan) dan daerah yang mengalami peningkatan produksi terbesar (Kabupaten Indramayu).
Perilaku usahatani menggambarkan bagaimana petani menggunakan sumberdaya secara efisien pada suatu usaha pertanian, dan bagaimana petani membuat keputusan dalam usaha pertanian. Oleh karena itu, dalam sebuah usaha pertanian diperlukan perencanaan dan pengkoordinasian penggunaan faktorfaktor produksi secara efisien untuk memperoleh pendapatan yang maksimal (Suratiyah, 2006).

Beberapa hasil penelitian menunjukkan penggunaan faktor-faktor 
produksi seperti pupuk, pestisida, bibit, dan tenaga kerja berpengaruh signifikan terhadap tingkat produksi berbagai komoditas (Asih, 2009; Tahir et al, 2010). Lebih lanjut, penelitian Kusumo et al (2018) menunjukkan pada usahatani mangga di Kabupaten Cirebon, kuantitas dan kualitas mangga yang dihasilkan petani dipengaruhi oleh perilaku petani mangga dalam aktivitas usahataninya. Menurunnya produksi mangga berhubungan dengan perilaku petani dimana sebagian petani belum menerapkan anjuran dosis dan waktu pemupukan, serta belum menerapkan zat pengatur tumbuh dan penanganan hama penyakit sesuai dengan anjuran.

Perbedaan tingkat produksi mangga di Kabupaten Indramayu dan Kuningan diduga berhubungan dengan perilaku petani dalam mengelola faktor-faktor produksinya. Berdasarkan pemaparan di atas, tujuan dari penelitian ini adalah untuk mengetahui: 1) perilaku petani dalam usahatani mangga di Kabupaten Indramayu dan Kuningan; 2) perbedaan perilaku petani dalam menjalankan usahatani mangga di Kabupaten Indramayu dan Kuningan.

\section{METODE PENELITIAN}

Penelitian dilakukan dengan metode survey-explanatory. Pengambilan sampel dilakukan dengan teknik multi-stage random sampling. Penelitian dilakukan di Kabupaten Indramayu dan Kuningan. Pemilihan lokasi ditentukan secara sengaja berdasarkan data wilayah yang mengalami peningkatan dan penurunan produksi terbesar pada data satu tahun terakhir. Dari masing-masing kabupaten terpilih 1 kecamatan, selanjutnya dari tiap kecamatan diambil satu desa sentra mangga. Masing-masing desa diambil responden petani secara acak 65 responden, sehingga jumlah total responden petani mangga sebanyak 130 orang. BPS mendefinisikan petani mangga adalah keluarga petani yang memiliki 4 pohon mangga atau lebih.

Variabel yang diteliti dalam penelitian ini adalah:

1. Karakteristik petani yang meliputi: umur, tingkat pendidikan, jumlah pohon yang diusahakan, pengalaman usahatani mangga, frekuensi mengikuti kegiatan penyuluhan, keanggotaan dalam kelompok tani, kemitraan dalam pemasaran, akses terhadap informasi mengenai budidaya mangga, dan pemasaran mangga.

2. Perilaku petani dalam agribisnis mangga adalah tindakan atau aktivitas yang dilakukan petani dalam menjalankan agribisnis mangga, meliputi perilaku dalam perawatan 
PERBANDINGAN PERILAKU USAHATANI PADA DUA SENTRA

PRODUKSI MANGGA DI PROVINSI JAWA BARAT

Rani Andriani Budi Kusumo, Elly Rasmikayati, Tuti Karyani, Gema Wibawa Mukti

tanaman, penerapan sistem pemupukan, penggunaan zat pengatur tumbuh, dan pengendalian organisme pengganggu tanaman yang diukur melalui item pertanyaan dengan 5 poin skala Likert (data ordinal); serta penerapan teknologi off season yang diukur dengan jawaban ya/tidak (data nominal).

Data yang digunakan dalam penelitian ini adalah data primer dan data sekunder. Data primer merupakan data yang diperoleh langsung dari hasil wawancara dengan petani mangga di Kabupaten Indramayu dan Kuningan. Sedangkan data sekunder diperoleh dari Badan Pusat Statistik, Dinas Pertanian Kabupaten Kuningan dan Indramayu, dan berbagai sumber lainnya. Teknik pengumpulan data dilakukan melalui: 1) wawancara dengan panduan kuesioner, dan 2) pengamatan langsung (observasi) di lokasi penelitian.

Analisis perilaku petani dalam menjalankan usahatani mangga di Kabupaten Kuningan dan Indramayu dilakukan dengan mengunakan analisis deskriptif. Sedangkan untuk menganalisis perbedaan perilaku petani dalam menjalankan usahatani mangga di Kabupaten Kuningan dan Indramayu digunakan análisis uji mann Whitney untuk data ordinal, dan uji chi square untuk data nominal.

\section{HASIL DAN PEMBAHASAN}

\section{Karakteristik Sosial Ekonomi Responden}

Karakteristik responden dijelaskan melalui karakteristik demografis dan juga informasi terkait usahatani mangga yang dijalankan oleh responden. Pada Tabel 2 dapat dilihat bahwa petani mangga di Kabupaten Indramayu dan Kuningan sebagian besar berada pada usia produktif, namun di Kabupaten Indramayu jumlah petani yang termasuk usia produktif lebih banyak dibandingkan dengan di Kabupaten Kuningan, dengan rata-rata umur petani yang lebih muda. Pada umumnya petani yang berusia lebih muda memiliki kemampuan fisik yang lebih besar dan lebih tanggap dalam menerima proses adopsi inovasi, sedangkan petani yang berumur lebih tua lebih berhati-hati dan penuh pertimbangan dalam menerima suatu inovasi baru (Batoa et al, 2008).

Tingkat pendidikan dapat memberikan gambaran mengenai tingkat pemahaman petani dan kemampuan petani untuk mencari solusi atas permasalahan yang dihadapinya. Mardikanto (1995) menyebutkan pendidikan merupakan proses pengembangan pengetahuan maupun sikap seseorang yang dilakukan secara terencana yang akan mengarahkan 
pada pengambilan keputusan. Berdasarkan tingkat pendidikan sebagian besar petani di kedua daerah penelitian hanya menyelesaikan sekolah hingga lulus sekolah dasar. Hanya sebagian kecil petani yang menempuh pendidikan ke jenjang yang lebih tinggi.

Jumlah pohon mangga menggambarkan skala usaha yang dijalankan oleh petani. Sebagian besar petani mengusahakan mangga dengan jumlah pohon di bawah 100 pohon (Tabel 2), dimana sebagian besar pohon adalah milik sendiri dan juga menyewa kepada pihak lain. BPS mendefinisikan petani dengan kepemilikan pohon mangga 4-10 pohon dikategorikan sebagai petani halaman (backyard farmer). Sedangkan petani yang memiliki 11 pohon keatas dikategorikan sebagai petani kebun (commercial farmer).

Pengalaman dapat menggambarkan kepemilikan pengetahuan yang dialami seseorang dalam kurun waktu yang tidak ditentukan (Batoa et al, 2008). Kebanyakan petani mangga di Kabupaten Indramayu dan Kuningan mengusahakan mangga secara turun temurun dari orangtua nya, dan sebagian besar petani memiliki pengalaman berusahatani mangga di bawah 20 tahun. Sejalan dengan tingkat usia petani, sebagian petani mangga di Kabupaten Kuningan memiliki pengalaman berusahatani lebih lama dibandingkan petani di Kabupaten Indramayu (Tabel 2).

Selain pendidikan formal, pendidikan nonformal pun dapat memberikan kontribusi terhadap peningkatan kompetensi petani (Manyamsari \& Mujiburrahmad, 2014). Penyuluhan sebagai salah satu bentuk pendidikan nonformal dimakni sebagai salah satu cara yang dilakukan untuk mendorong terjadinya perubahan perilaku baik pada tataran individu, kelompok, komunitas maupun manyarakat agat petani tahu, mau dan mampu menyelesaikan masalah (Amanah, 2007). Petani di Kabupaten Indramayu dan Kuningan sebagian besar tidak pernah mengikuti kegiatan penyuluhan (Tabel 2).

Untuk menyelesaikan permasalahan yang dihadapi biasanya petani mencari informasi dari sesama petani lain. Hal ini menjadi kendala bagi petani dalam menjalankan usahataninya. Sebagian besar petani berpendapat bahwa mereka masih membutuhkan bimbingan untuk meningkatkan pengetahuan dan keterampilan dalam berusahatani mangga.

Kelompok tani merupakan organisasi yang berfungsi sebagai wahana kerjasama dan penggerak kegiatan anggota. Secara filosofis kelompok tani dibentuk untuk memecahkan masalah 
sehingga petani bisa berproduksi secara optimal dan efisien (Nuryanti \& Swastika, 2011). Namun sayangnya di kedua lokasi penelitian, kelompok tani belum berfungsi optimal, sehingga sebagian besar petani tidak tergabung dalam kelompok tani.

Tabel 2. Karakteristik Sosial Ekonomi Responden

\begin{tabular}{|c|c|c|c|c|}
\hline \multirow[t]{2}{*}{ Karakteristik } & \multicolumn{2}{|c|}{$\begin{array}{c}\text { Petani di Kabupaten } \\
\text { Indramayu }\end{array}$} & \multicolumn{2}{|c|}{$\begin{array}{c}\text { Petani di Kabupaten } \\
\text { Kuningan }\end{array}$} \\
\hline & n (orang) & $\%$ & n (orang) & $\%$ \\
\hline \multicolumn{5}{|l|}{ Umur } \\
\hline Produktif (15-64 tahun) & 62 & 95,38 & 45 & 69,23 \\
\hline Non Produktif ( $>64$ tahun) & 3 & 4,62 & 20 & 30,77 \\
\hline Rata-rata umur petani & \multicolumn{2}{|c|}{45 tahun } & \multicolumn{2}{|c|}{56 tahun } \\
\hline \multicolumn{5}{|l|}{ Tingkat pendidikan } \\
\hline Tidak Sekolah & 7 & 10,77 & 4 & 6,15 \\
\hline SD & 40 & 61,54 & 52 & 80,00 \\
\hline SMP & 13 & 20,00 & 3 & 4,62 \\
\hline SMA & 5 & 7,69 & 3 & 4,62 \\
\hline Diploma & - & 0 & 2 & 3,08 \\
\hline Sarjana & - & 0 & 1 & 1,54 \\
\hline \multicolumn{5}{|l|}{ Jumlah pohon yang diusahakan } \\
\hline$\leq 10$ & 9 & 13,85 & 29 & 44,62 \\
\hline $11-100$ & 31 & 47,69 & 34 & 52,31 \\
\hline $101-200$ & 9 & 13,85 & 2 & 3,08 \\
\hline $201-300$ & 6 & 9,23 & - & 0 \\
\hline $301-400$ & 2 & 3,08 & - & 0 \\
\hline$\geq 401$ & 10 & 15,38 & - & 0 \\
\hline \multicolumn{5}{|l|}{ Pengalaman usahatani (tahun) } \\
\hline $0-10$ & 39 & 60,00 & 30 & 46,15 \\
\hline $11-20$ & 25 & 38,46 & 20 & 30,77 \\
\hline $21-30$ & 1 & 1,54 & 10 & 15,38 \\
\hline $31-40$ & - & 0 & 3 & 4,62 \\
\hline $41-50$ & - & 0 & 2 & 3,08 \\
\hline$>50$ & - & 0 & - & 0 \\
\hline \multicolumn{5}{|c|}{$\begin{array}{l}\text { Frekuensi mengikuti kegiatan penyuluhan } \\
\text { (per tahun) }\end{array}$} \\
\hline tdk pernah & 55 & 84,62 & 51 & 78,46 \\
\hline $1-2 \mathrm{x}$ & 10 & 15,38 & 14 & 21,54 \\
\hline $3-6 \mathrm{x}$ & - & 0 & - & 0 \\
\hline \multicolumn{5}{|c|}{ Keanggotaan dalam kelompok tani } \\
\hline $\mathrm{Ya}$ & 3 & 4,62 & - & 0 \\
\hline Tidak & 62 & 95,38 & 65 & 100,00 \\
\hline
\end{tabular}

Perilaku Petani dalam Usahatani Mangga di Kabupaten Indramayu dan Kuningan

Perilaku usahatani diukur berdasarkan pernyataan petani mengenai penggunaan faktor-faktor produksi dalam usahatani mangga. Sebagian besar pohon mangga yang diusahakan oleh petani adalah pohon milik sendiri dan sebagian kecil adalah pohon yang diusahakan melalui sistem sewa. Pada Tabel 3 dapat dilihat bahwa sebagian besar petani di Kabupaten Indramayu dan Kuningan cukup intensif dalam melakukan pemeliharaan terhadap pohon mangga 
agar pohon tersebut dapat berproduksi secara optimal, namun masih ada sebagian kecil petani yang kurang melalukan pemeliharaan terhadap pohon mangga miliknya. Dari hasil wawancara terlihat bahwa jumlah pohon yang diusahakan berhubungan dengan intensitas pemeliharaan tanaman mangga. Hal ini sejalan dengan hasil penelitian Rasmikayati et al (2018) yang menunjukkan petani dengan kepemilikan pohon mangga yang lebih banyak cenderung lebih intensif dalam melakukan pemeliharaan tanaman mangga, dan sebaliknya petani dengan kepemilikan pohon yang terbatas cenderung mengusahakan mangga seadanya. Bentuk pemeliharaan yang paling sering dilakukan oleh petani adalah pemberian pupuk. Tidak terdapat perbedaan nyata antara perilaku petani di Kabupaten Indramayu dan Kuningan dalam hal intensitas pemeliharaan pohon mangga $(\mathrm{p}>0,05)$. Dalam aktivitas pemupukan, sebagian besar petani di Kabupaten Indramayu dan Kuningan menyatakan telah menerapkan sistem pemupukan sesuai dengan anjuran (Tabel 3) dan tidak terdapat perbedaan perilaku petani dalam menerapkan sistem pemupukan sesuai dengan anjuran $(p>0,05)$. Pupuk yang digunakan oleh petani adalah pupuk kandang dan pupuk NPK. Balai
Pengkajian Teknologi Pertanian (BPTP) Jawa Barat menganjurkan untuk tanaman mangga perlakuan pemberian pupuk kandang dan pupuk buatan diberikan pada musim penghujan. Pupuk kandang dengan takaran 30-40 kg/pohon diberikan dengan cara menggemburkan tanah terlebih dahulu, kemudian pupuk kandang dicampur dengan tanah di sekitar perakaran tanaman. Dua minggu setelah pemberian pupuk kandang, dilanjutkan dengan pemberian pupuk buatan dengan dosis sekitar 3,5 $\mathrm{kg}$ pupuk NPK Mutiara 16.16.16. Namun, masih terdapat sekitar $25 \%$ petani di Kabupaten Indramayu dan Kuningan yang belum menerapkan sistem pemupukan sesuai dengan anjuran. Agustian, et al (2005) menyebutkan berfluktuasinya harga jual mangga membuat petani ragu-ragu untuk menerapkan sistem budidaya mangga secara intensif melalui peningkatan masukan input usahatani sesuai anjuran.

Penggunaan zat pengatur tumbuh (ZPT) dalam usahatani mangga bertujuan untuk merangsang pembungaan tanaman mangga. ZPT yang banyak digunakan oleh petani adalah Paklobutrazol. Sebagian besar petani di Kabupaten Indramayu dan Kuningan telah menggunakan ZPT sesuai dengan anjuran Dinas Pertanian (Tabel 3). Todak terdapat 
perbedaan perilaku petani dalam

penggunaan ZPT $(\mathrm{p}>0,05)$.

Tabel 3. Perilaku Petani dalam Usahatani Mangga

\begin{tabular}{|c|c|c|c|c|}
\hline \multirow[t]{2}{*}{ Perilaku Usahatani } & \multicolumn{2}{|c|}{$\begin{array}{c}\text { Petani di Kabupaten } \\
\text { Indramayu } \\
\end{array}$} & \multicolumn{2}{|c|}{$\begin{array}{c}\text { Petani di Kabupaten } \\
\text { Kuningan }\end{array}$} \\
\hline & n (orang) & $\%$ & n (orang) & $\%$ \\
\hline \multicolumn{5}{|l|}{$\begin{array}{l}\text { Merawat pohon mangga agar produktvitasnya } \\
\text { tinggi }\end{array}$} \\
\hline Selalu & 6 & 9,23 & 5 & 7,69 \\
\hline Sering & 54 & 83,08 & 53 & 81,54 \\
\hline Kadang-kadang & 1 & 1,54 & 5 & 7,69 \\
\hline Jarang & 1 & 1,54 & 1 & 1,54 \\
\hline \multirow[t]{2}{*}{ Tidak pernah } & 3 & 4,62 & 1 & 1,54 \\
\hline & \multicolumn{4}{|c|}{$\mathrm{p}=0,580$} \\
\hline \multicolumn{5}{|l|}{$\begin{array}{l}\text { Menerapkan sistem pemupukan yang benar } \\
\text { (dalam hal jenis, dosis atau waktu pemupukan) }\end{array}$} \\
\hline Selalu & 3 & 4,62 & 4 & 6,15 \\
\hline Sering & 46 & 70,77 & 45 & 69,23 \\
\hline Kadang-kadang & 3 & 4,62 & 9 & 13,85 \\
\hline Jarang & 13 & 20,00 & 7 & 10,77 \\
\hline \multirow[t]{2}{*}{ Tidak pernah } & - & 0 & - & 0 \\
\hline & \multicolumn{4}{|c|}{$p=0,676$} \\
\hline \multicolumn{5}{|l|}{$\begin{array}{l}\text { Menggunakan ZPT (zat pengatur tumbuh) } \\
\text { sesuai aturan pakai }\end{array}$} \\
\hline Selalu & 5 & 7,69 & 8 & 12,31 \\
\hline Sering & 52 & 80,00 & 46 & 83,64 \\
\hline Kadang-kadang & 3 & 4,62 & 7 & 10,77 \\
\hline Jarang & 4 & 6,15 & 3 & 4,62 \\
\hline \multirow[t]{2}{*}{ Tidak pernah } & 1 & 1,54 & 1 & 1,54 \\
\hline & \multicolumn{4}{|c|}{$p=0,268$} \\
\hline \multicolumn{5}{|l|}{$\begin{array}{l}\text { Mengendalikan OPT dengan Benar (misalnya } \\
\text { penanganan hama lalat buah dan hama } \\
\text { lainnya) }\end{array}$} \\
\hline Selalu & 1 & 1,54 & 1 & 1,54 \\
\hline Sering & 60 & 92,31 & 25 & 38,46 \\
\hline Kadang-kadang & 1 & 1,54 & 1 & 1,54 \\
\hline Jarang & 3 & 4,62 & 28 & 43,08 \\
\hline \multirow[t]{2}{*}{ Tidak pernah } & - & 0 & - & 0 \\
\hline & \multicolumn{4}{|c|}{$\mathrm{p}=0,000$} \\
\hline \multicolumn{5}{|l|}{ Menerapkan Teknologi Off Season } \\
\hline $\mathrm{Ya}$ & 62 & 95,38 & 15 & 23,08 \\
\hline \multirow[t]{2}{*}{ Tidak } & 3 & 4,62 & 40 & 61,54 \\
\hline & \multicolumn{4}{|c|}{$\mathrm{p}=0,000$} \\
\hline
\end{tabular}

Menurut sebagian besar petani, organisme pengganggu tanaman (OPT) yang sering menyerang tanaman mangga adalah lalat buah. Curah hujan yang tinggi mendorong perkembangan populasi lalat buah. Gejala serangan lalat buah terlihat berupa bercak-bercak coklat dan lubang bekas tusukan lalat buah. Dalam hal penanganan hama dan penyakit terdapat perbedaan perilaku petani dalam 
menerapkan pengendalian OPT $(\mathrm{p}<0,05)$. Sebagian besar petani di Kabupaten Indramayu telah menggunakan cara pengendalian OPT sesuai dengan anjuran; namun separuh responden di Kabupaten Kuningan masih belum intensif mengendalikan OPT terutama serangan lalat buah (Tabel 3). Sebagian besar petani menggunakan pestisida untuk mengendalikan lalat buah dan sebagian petani menggunakan perangkap hama. Dinas Tanaman Pangan dan Hortikultura Provinsi Jawa Barat (2000) menyebutkan perlakuan pengendalian lalat buah dapat dilakukan dengan menggunakan cara fisik/mekanis yaitu membungkus buah ketika buah masih sebesar kelereng, dan pemasangan atraktan metil eugenol, ekstrak selasih/meulaleuca dan menggunakan umpan protein pada saat tanaman baru perbuah sampai panen. Selain secara fisik, pengendalian lalat buah juga dapat dilakukan dengan memanfaatkan musuh alami parasitoid serta menjaga sanitasi kebun. Berdasarkan hasil wawancara, di Kabupetan Kuningan serangan lalat buah cukup meningkat pada satu tahun terakhir, akibatnya banyak buah mangga yang busuk sehingga produksi buah mangga menurun. Menurut petani penggunaan pestisida belum efektif dalam mengatasi serangan lalat buah, apalagi di saat curah hujan tinggi.

Dalam penerapan teknologi off season, terdapat perbedaan proporsi petani yang menerapkan teknologi off season di Kabupaten Indramayu dan Kuningan $(p<0,05)$; dimana sebagian besar petani di Kabupaten Indramayu telah menerapkan teknologi off season, sedangkan sebagian besar petani di Kabupaten Kuningan tidak menerapkan teknologi off season (Tabel 3). Keputusan petani untuk tidak melakukan usahatani di luar musim disebabkan karena petani merasa bahwa tanaman juga membutuhkan waktu untuk beristirahat. Selain itu kegiatan pemeliharaan di luar musim dirasa sulit dan menggunakan banyak tenaga, serta modal yang cukup besar. Hasil penelitian Kusumo, et al (2018) di Kabupaten Cirebon menunjukkan keputusan petani dalam menerapkan teknologi off season lebih dipengaruhi oleh faktor yang berasal dari luar diri petani, yaitu frekuensi kegiatan penyuluhan, kemitraan dalam hal pemasaran, permintaan buah mangga, dan ketersediaan sarana produksi. Perbedaan perilaku petani di Kabupaten Indramayu dan Kuningan diduga menjadi faktor yang turut mempengaruhi tingkat produksi mangga di Kabupaten Indramayu dan Kuningan. 


\section{KESIMPULAN DAN SARAN}

Petani mangga di Kabupaten Indramayu dan Kuningan melakukan perawatan tanaman mangga secara intensif. Tidak terdapat perbedaan perilaku petani dalam hal perawatan tanaman, penerapan sistem pemupukan dan penggunaan zat pengatur tumbuh. Sebagian besar petani di Kabupaten Indramayu dan Kuningan telah menerapkan sistem pemupukan dan penggunaan zat pengatur tumbuh sesuai dengan anjuran. Dalam hal pengendalian OPT terdapat perbedaan perilaku petani di Kabupaten Indramayu dan Kuningan, dimana sebagian besar petani di Kabupaten Indramayu intensif dalam mencegah dan mengatasi serangan OPT, sedangkan sebagian petani di Kabupaten Kuningan belum intensif dalam mengendalikan serangan OPT dan hal ini diduga berpengaruh terhadap hasil produksi petani. Sebagian besar petani di Kabupaten Indramayu telah menerapkan teknologi off season, dan sebaliknya sebagian besar petani di Kabupaten Kuningan belum menerapkan teknologi off season.

Perlu dilakukan penelitian lebih lanjut untuk mengetahui apakah perbedaan perilaku usahatani yang dianalisis dalam penelitian ini, terbukti berpengaruh terhadap tingkat produksi mangga. Hasil tersebut diharapkan dapat memberikan masukan mengenai upaya yang dapat dilakukan untuk meningkatkan produksi mangga sehingga pendapatan petani dapat meningkat.

\section{DAFTAR PUSTAKA}

Agustian, A., Armen, Z., Syahtuti. Supriatna, A., Tarigan, H., Yana, S., Nurasa, T. 2005. Analisis Berbagai Bentuk Kelembagaan Pemasaran dan Dampaknya terhadap Kinerja Usaha Komoditas Sayuran dan Buah. Laporan Akhir. Pusat Penelitian dan Pengembangan Sosial Ekonomi Pertanian. Badan Penelitian dan Pengembangan Pertanian

Amanah, S. 2007. Makna Penyuluhan dan Transformasi Perilaku Manusia. Jurnal Penyuluhan, 3(1): 63-67.

Asih, D.N. 2009. Analisis Karakteristik dan Tingkat Pendapatan Usahatani Bawang Merah di Sulawesi Tengah. Jurnal Agroland, 16(1): 53-59.

Batoa, H., Jahi, A., Susanto, D. 2008. Faktor-faktor yang Berhubungan dengan Kompetensi Petani Rumput Laut di Kabupaten Konawe Provinsi Sulawesi Tenggara. Jurnal Penyuluhan, 4(1): 30-38.

BPS. 2018. Data Produksi Buah-buahan Menurut Kabupaten/Kota di Jawa Barat. $\quad$ http://jabar.bps.go.id. Diakses 30 Desember 2018.

Dinas Tanaman Pangan dan Hortikultura Provinsi Jawa Barat. 2000. Pedoman Pengamatan dan Pelaporan OPT Hortikultura. http://distan.jabarprov.go.id. Diakses 20 Januari 2019.

Manyamsari, I., Mujiburrahmad. 2014. Karakteristik Petani dan Hubungannya dengan Kompetensi 
Petani Lahan Sempit. Jurnal Agrisep, 15(2): 58-74.

Mardikanto, T. 1993. Penyuluhan Pembangunan Pertanian. Surakarta (ID): Sebelas Maret University Press.

Nuryanti, S., Swastika, D.K.S. 2011. Peran Kelompok Tani dalam Penerapan Teknologi Pertanian. Forum Penelitian Agro Ekonomi, 29(2): 115-128.

Kusumo, R.A.B., Rasmikayati, E., Mukti, G.W. Fatimah, S., Saefudin, B.R. 2018. Faktor-faktor yang Mempengaruhi Keputusan Petani Mangga dalam Menggunakan Teknologi Off Season di Kabupaten Cirebon. Mimbar Agribisnis, 4(1): 57-69.
Kusumo, R.A.B., Rasmikayati, E., Mukti, G.W. 2018. Perilaku Petani dalam Usahatani Mangga di Kabupaten Cirebon. Mimbar Agribisnis, 4(2): 197-209.

Rasmikayati, E., Mukti, G.W., Kusumo, R.A.B., Fatimah, S., Saefudin, B.R. 2018. Potensi dan Kendala dalam Proses Usahatani dan Pemasaran Mangga di Kabupaten Indramayu. Jurnal Sosiohumaniora, 20(3): 215221.

Suratiyah, K. 2006. Ilmu Usahatani. Jakarta (ID): Penebar Swadaya.

Tahir, A.G., Darwanto, D.H., Mulyo, J. H., Jamhari. 2010. Analisis Efisiensi Produksi Sistem Usahatani Kedelai di Sulawesi Selatan. Jurnal Agroekonomi, 28(2): 133-151. 